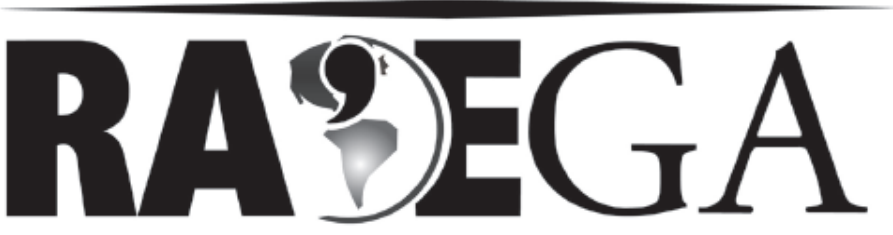

O ESPAÇO GEOGRÁFICO EM ANÁLISE

\title{
RELIGIÃO E ESPACIALIZAÇÃO
}

\section{RELIGION AND SPATIALIZATION}

\author{
Alex Sandro da Silva ${ }^{1}$
}

\section{RESUMO}

O espaço sagrado se organiza em vários níveis. No entanto, grande parte das teorias em geografia da religião abrange apenas as manifestações materializadas do fenômeno religioso. Observando a religião sob o enfoque de outras ciências sociais é possível argumentar ser ela melhor caracterizada pela capacidade de incentivar certos modelos de conduta. Partindo disso, com o apoio de Ernst Cassirer e Gilbert Durand foi possível concatenar uma teorização, através da qual se torna propício observar a religião por meio dos universos simbólicos e dos espaços por eles engendrados num processo contínuo, dinâmico e retroalimentável de espacialização.

Palavras-chave: Religião; Espaço; Símbolo; Ação; Espacialização.

\section{ABSTRACT}

Sacred space is structured on several levels. However, most theories in geography of religion anlyses merely the materialized manifestations of sacred. Trough others social sciences is possible to argue that the religion is best characterized by power to encourage types of certain behaviors. Following this premise, based in Ernst Cassirer and Gilbert Durand was possible to construct a theory to approach religion phenomena like a continuous, dynamic and feedbackable process of spatialization. Studying the sacred space through this aproach, there is a possibility of unveiling others levels of spatializations, which would be useful to examine formation and spatial diffusion of recent religious movements.

\footnotetext{
${ }^{1}$ Mestre pelo Programa de Pós-Graduação em Geografia da Universidade Federal do Paraná - UFPR, Curitiba, Paraná, Brasil. alexnrocks@gmail.com
} 
Keywords: Religion; Space; Symbols; Action; Spatialization.

\section{INTRODUÇÃO}

O presente trabalho nasceu de uma reflexão enfrentada pelo autor durante a execução de sua dissertação de mestrado - "Religião e Espacialização: O caso da Igreja Internacional da Graça de Deus" - no programa de pós-graduação em geografia da Universidade Federal do Paraná.

$\mathrm{Na}$ busca por oferecer respaldo teórico às especificidades do fenômeno estudado, havia desde as primeiras reflexões uma dúvida: a centralidade da análise. Poder-se-ia construir uma dissertação analisando apenas as manifestações concretas da religião, porém para o caso estudado as ações do devoto pareciam prevalecer sobre o concreto do espaço.

Dessa preponderância nasceu o problema fundamental que moveu toda reflexão teórica. Se por espaço sagrado fossem compreendidas apenas coisas sagradas, tais como templos, cidades ou monumentos, como seria possível realizar um estudo de geografia sobre manifestações religiosas que não dispõe no espaço fixo o elemento sagrado? Esse problema proporcionou a busca por uma teoria no qual o elemento humano fosse o centro da análise espacial.

Por intermédio deste artigo apresentar-se-á a teorização arranjada para a construção da dissertação. Arranjo teórico esse construído no intuito de abranger e responder satisfatoriamente às especificidades referentes a fenômenos religiosos recentes, no qual o que mais se destaca, ao invés do espaço construído, é o espaço sagrado em construção.

\section{GEOGRAFIA E RELIGIÃO}

A geografia da religião não é um campo novo na seara das reflexões humanas. Originada nas preocupações teóricas dos filósofos da antiga Grécia, estudos nesse campo já assumiam importância e produção de considerável volume durante o período do renascimento europeu e das navegações (PARK, 1994; KONG, 1990).

Entre os séculos XVI e XIX, pesquisas sobre as manifestações 
espaciais da religião eram predominantemente realizadas sob a influência de princípios religiosos. Naquele momento os pesquisadores buscavam: descrever a propagação do cristianismo pelo mundo; compreender as esferas de influência das religiões sobre uma dada região; e explicar os eventos bíblicos de acordo com os conhecimentos daquela época (PARK, 1994).

A partir do século XIX, as abordagens passaram, paulatinamente, dos paradigmas teológicos às leis naturais. Inspirados pela visão científica, os pesquisadores procuravam demonstrar como o ambiente influenciava, ou mesmo determinava, as peculiaridades pelas quais se manifestava o fenômeno religioso (PARK, 1994).

Até metade do século $X X$, na maior parte dos estudos imperava o determinismo ambiental. Esses trabalhos dificilmente ultrapassavam o nível descritivo, além do mais, neles não se encontravam explicações a respeito dos possíveis impactos da religião sobre o ambiente, ou, ao menos, ofereciam a isso algum indicativo (FICKELER, 1999).

Uma significativa mudança na forma de conceber as características espaciais do fenômeno religioso foi alcançada através de um diálogo maior com as ciências da religião. Através de suas contribuições, ao invés de examinar apenas a manifestação concreta da religião no espaço, ao geógrafo foi possibilitado estudar o fenômeno com mais profundidade (CLAVAL, 1999).

Isso permitiu o desenvolvimento de uma geografia mais compromissada com uma essência religiosa do fenômeno religioso. Através da fenomenologia e das ciências da religião, o espaço do fenômeno religioso deixou de ser considerado apenas em suas manifestações concretas. Uma essência religiosa presente no homem também se tornaria objeto de análise do espacializar da religião. No entanto, a abordagem mais empregada até os dias atuais é aquela que se prende às manifestações concretas da religião no espaço.

No que se refere ao desenvolvimento da geografia da religião praticada no Brasil, atualmente encontramos duas importantes e profícuas correntes.

O arcabouço teórico tecido por Rosendahl (2002, 2009a, 2009b), é muito influente sobre trabalhos em geografia da religião. Nessa abordagem 0 
enfoque principal recai principalmente sobre os templos, os lugares sagrados, as cidades sagradas e os centros de irradiação religiosa, os quais por sua essência sacra influenciam o elemento humano em seus deslocamentos e qualificações. Quando são consideradas as estruturas organizacionais, o fenômeno religioso é inserido dentro do jogo das relações de poder institucionais.

Já outro grupo de pesquisadores (GIL FILHO, 2000, 2001, 2004, 2006; SAHR, 2001, 2003, 2006, 2009) busca realizar seus estudos partindo de uma base fenomenológica. Presume-se ser possível vislumbrar o espaço da religião através do espaço de ação do fiel. São as representações, as percepções do fiel em face do discurso religioso, os estruturantes do fenômeno religioso. Dentro dessa perspectiva, quando são realizados trabalhos sobre as territorialidades institucionais, concebe-se que as mesmas são marcadas muito mais que o aspecto visível dos templos pelos intercâmbios simbólicos que se organizam no entorno das relações de poder.

Resumidamente, a heterogeneidade teórica encontrada gravita no entorno do grau de importância dos elementos, religioso, humano e espacial na conformação das teorias espaciais do fenômeno religioso. Fruto dessas diferenças é o amadurecimento da disciplina.

Como observado anteriormente, a Geografia da Religião se enriqueceu e continua se aprimorando através de maior diálogo com outras disciplinas científicas, partindo disso, é importante também refletir a religião pelo olhar dessas outras ciências da religião.

\section{CONTRIBUIÇÕES TÉORICAS DE OUTRAS DISCIPLINAS À GEOGRAFIA DA RELIGIÃO}

Uma importante contribuição da sociologia à geografia da religião foi oferecer ao pesquisador a ideia de que ao invés de a religião ser determinada pelo ambiente, seria ela, primeiramente, influente sobre as ações humanas e sociais, as quais provocariam mudanças no espaço. Dentro da sociologia, quando se pensa em religião, referências necessárias são os pioneiros trabalhos realizados por Karl Marx (1818-1883), Emile Durkheim (1858-1917) e 
Max Weber (1864-1920).

Karl Marx pode não ser propriamente considerado um sociólogo da religião, no entanto a extensão da influência de seu modo de pensar a sociedade sobre as ciências sociais demanda atenção especial às suas considerações.

Para Marx e Engels (1976), não é habitante da natureza humana a originalidade da religião, antes disso, é ela subproduto das ações situadas no entorno das relações de produção e reprodução material das sociedades. No pensamento marxiano a religião como uma ideologia se apresentaria como reflexo da vida material estando condicionada às mudanças ocorridas no decorrer da história.

Outra influente forma de se visualizar o fenômeno religioso foi tecida através do olhar de Max Weber. A sociologia da ação de Weber (1982, 2001), leva em consideração as influências deixadas por uma determinada ética religiosa sobre a ética econômica e, por conseguinte, como essa se traduz no comportamento econômico de um grupo religioso. Em Psicologia Social das Religiões Mundiais, Weber (1982, p.299) define ética econômica de uma religião como os "[...] impulsos práticos de ação que se encontram nos contextos psicológicos e pragmáticos das religiões."

Vale ressaltar que o autor elege a relação entre economia e religião como tema de estudo não reduzindo um campo ao outro. Até mesmo sobre a ética econômica, Weber (1982, p.310) adverte que nenhuma delas foi "determinada exclusivamente pela religião".

Outra contribuição da sociologia de Weber para os estudos da religião, principalmente, da ação humana motivada pela ética religiosa, reside em sua teorização a respeito das autoridades carismáticas, a noção de Carisma de Weber pode ser usada de forma competente em estudos que envolvam o surgimento de novas lideranças religiosas. Para Weber (1982, p.283-284) os líderes carismáticos são os guias naturais das "[...] épocas de dificuldades psíquicas, físicas, econômicas, éticas, religiosas ou políticas" [...] "os quais nas dificuldades foram os portadores de dons específicos do corpo e do espírito dons esses considerados sobrenaturais não acessíveis a todos." O líder 
carismático promoveria a mudança, pois se colocaria ao lado das estruturas burocráticas e patriarcais que regem as rotinas.

Dessa forma, Weber construiu uma visão dinâmica da religião, na qual os agentes, inseridos numa ética religiosa com sua forma característica de se relacionar com o mundo, são predispostos a agir em determinadas direções, o que favoreceria ou não o maior desenvolvimento de sistemas econômicos. Por outro lado, mudanças estruturais, dentro de determinados ambientes, poderiam provocar através do surgimento dos líderes carismáticos mudanças nas religiões, bem como na forma de ação dos crentes em relação ao seu mundo.

Houve pouca penetração das ideias de Weber na geografia da religião (CLAVAL, 1999). No entanto, após a década de 1920, alguns pesquisadores passaram a considerar a religião como fator de influência na construção do espaço, o que era diametralmente oposto à versão determinista predominante (KONG, 1990). Porém, mesmo que essas ideias abrissem novos horizontes aos estudos em geografia da religião, o determinismo ambiental perdurou, ainda, até meados da década de 50 do século passado (BÜTTNER apud PARK, 1994).

Outro autor que voltou seu olhar as manifestações religiosas foi Emile Durkheim. Sua teoria sociológica posiciona a religião como manifestação do anseio do Homem pela construção de uma organização social. De antemão, se posicionando contra os estudiosos que buscavam fazer da religião uma manifestação do irreal ou do absurdo, Durkheim (2005, p.148) defendeu que nenhuma instituição humana com a perenidade apresentada pelas manifestações religiosas se assentaria no erro ou na mentira; pois se assim fosse teria encontrado fortes resistências na própria natureza das coisas e não teria conseguido durar.

Para o autor a religião é "uma coisa eminentemente social" que pode ser concebida como um sistema de crenças e de práticas organizadas no entorno das coisas sagradas. No qual as crenças seriam formadas por representações, que ao supor "uma classificação das coisas, reais ou ideais" em duas classes e gêneros opostos (sagrado e profano), propiciariam a ação (DURKHEIM, 2003). 
As representações presentes nas crenças serviriam para objetivar a classificação, ou mesmo, explicação das coisas do mundo material ou ideal. Através dessa classificação tais coisas seriam matizadas numa coloração religiosa expressa pelo seu caráter sagrado ou profano, essa organização propiciaria as práticas religiosas.

Tomando a sociedade como a fonte do pensamento, o autor expõe que a causa objetiva das sensações das quais se forma a experiência religiosa é a própria vida em sociedade. Sobre isso Durkheim (2005, p.169) conclui que tendo a religião engendrado "[...] tudo o que há de essencial na sociedade, é que a idéia da sociedade é alma da religião."

De forma resumida, a sociologia de Durkheim toma a religião como um fato referente à organização da sociedade. A religião aproxima os homens para uma vida em comunidade, as crenças de uma religião são representações coletivas provedoras de realidades coletivas, os ritos são formas de agir cuja função esta ligada a necessidade de criação e recriação das disposições mentais que dão identidade a um determinado grupo social, o fortalecendo.

Outro sociólogo que não necessariamente tendo a religião como principal objeto de reflexão trouxe importante contribuição a abordagem do tema foi Pierre Bourdieu. Para o autor (2009), duas tradições teóricas vinham se firmando frente ao fenômeno religioso, no entanto delas poderia ser extraído um núcleo comum. Uma das tradições postulava que a religião se posicionava entre as relações de poder e de lutas entre as classes sociais, a outra a observava como um sistema simbólico que operava através das representações por organizar a sociedade. O ponto comum defendido pelo autor residia no fato de que sendo um sistema simbólico estruturado com a função de organizar as relações sociais, a religião operaria por manter as relações de poder e de organização social já presente na sociedade.

Para o autor, a religião, por meio de seu conjunto de representações, legitimaria as coisas do mundo. A religião ao situar no transcendente a gênese das estruturas de poder e de classes naturalizaria as relações de poder e divisões da sociedade. Essa naturalização das relações sociais incutida nas disposições mentais humanas proporcionaria uma opacidade que furtaria do 
homem a consciência do teor arbitrário das secções políticas e sociais.

Bourdieu contribuiu para a compreensão do fenômeno religioso, ao demonstrar como ele se insere nas relações de poder existentes no seio da sociedade. A visão desse autor corresponde, mais propriamente, a uma concepção europeia de religião, o que favorece a análise de instituições religiosas tradicionais como a Igreja Católica.

Outra disciplina que oferece contribuições teóricas à geografia da religião é a antropologia. Um autor que fomenta em termos de definição de religião alguns trabalhos em geografia da religião (ver SAHR e MARINO, 2009) é Clifford Geertz.

Para Geertz (1989, p.104-105) a religião pode ser considerada como: "um sistema de símbolos que atua para estabelecer poderosas, penetrantes e duradouras disposições e motivações nos homens através da formulação de conceitos de uma ordem de existência geral e vestindo essas concepções com tal aura de fatualidade que as disposições e motivações parecem singularmente realistas."

Além desses autores, os quais partindo de um viés empirista e simbólico da religião viam-na, sobretudo, como articulada à ação social e a sociedade, outra tradição se formou e foi muito desenvolvida até metade do século passado: a fenomenologia da religião, que trouxe grande contribuição aos estudos em geografia. Sob a influência dessa corrente, alguns geógrafos passaram a se dedicar um pouco mais às experiências religiosas do devoto.

Os seguidores da fenomenologia da religião organizaram um corpo teórico que prometia transcender às análises profundamente secularizadas do fenômeno. Eles operaram por manter suas investigações circunscritas ao viés propriamente sagrado da religião.

Em respeito ao sagrado, como categoria de compreensão do fenômeno religioso, sua definição remonta a obra Das Heilige (O Sagrado), publicada, pelo teólogo e filósofo alemão Rudolf Otto (1869-1937), em Marburgo na Alemanha em 1917. Otto (2007) defende que a compreensão do fenômeno religioso deve ser realizada através da própria realidade religiosa. Ponderando sobre o termo heilig (sagrado) o autor busca demonstrar que o linguajar 
filosófico e teológico com o passar do tempo passou a designar através do termo um "atributo absolutamente moral", como algo "perfeitamente bom". A partir dessa constatação, no intuito de apontar a característica propriamente religiosa das manifestações religiosas, Otto (2007) redimensiona o termo ao seu universo primordial, construindo, dessa forma, uma categoria de análise que, segundo ele, propiciaria o estudo do fenômeno verdadeiramente religioso.

O sagrado seria uma categoria que comportaria elementos racionais dispostos na forma de conhecimento e tradição religiosa e não racionais expressas pelo objeto propriamente religioso. No qual "[...] o elemento não racional (numinoso) seria o predicador e o elemento racional o predicado". Dessa forma o acesso racional ao divino se daria por uma necessidade da razão de esquematizar o elemento não racional constitutivo da experiência com o numinoso (BIRCK, 1993, p.14).

Uma investigação científica que buscasse respaldo no conceito de sagrado de Otto deveria, sobretudo, ater-se àquela categoria que designa 0 elemento propriamente religioso e não racional. No entanto, essa categoria não possui definição conceitual, apenas podendo ser discutida. $O$ numinoso somente pode ser apreendido através de um sentimento desencadeado na psique, é o arrepio, de medo, do pavor experimentado pelo espírito face ao inefável, a aquilo que não pode ser descrito por palavras, mas pode ser sentido pela criatura, numa experiência religiosa, diante do criador (OTTO, 2007).

Alguns importantes teóricos sagraram suas análises através dos pressupostos da fenomenologia da religião. Exemplo foi Joachim Wach (1990), cujos estudos voltaram-se a sistematização das formas de expressão da experiência religiosa no meio social.

Wach (1990) dividiu as formas de expressão da experiência religiosa em três dimensões: a primeira se conformaria por ser a dimensão da expressão teórica, em que a religião seria organizada no entorno das tradições orais e textuais; a segunda seria a esfera própria da expressão prática, pela qual a experiência religiosa se manifestaria nas ações do homem religioso; uma terceira esfera seria referente àquela, na qual se realizaria a expressão sociológica da religião, a qual complementando as duas anteriores daria à 
religião um caráter social. Porém, ressalva o autor, que não se podem separar completamente essas esferas, o melhor exemplo disso seria ilustrado pela vida dos fundadores das religiões. Os quais através de suas ações doutrinárias anulariam a divisão entre a esfera prática e a teórica.

Outro autor que em sua carreira se dedicou ao sagrado foi o escritor e historiador romeno Mircea Eliade (1907-1986). A obra O Sagrado e o Profano foi bastante influente sobre os trabalhos de geografia da religião. Nesse texto de Eliade (1996), a ideia central gira em torno de uma oposição entre o sagrado e o profano, no qual a manifestação do sagrado criaria pontos qualitativamente diferenciados que auxiliariam na ordenação cognitiva do mundo.

Através da manifestação do sagrado, as hierofanias, o espaço tornarse-ia o centro do mundo. Como essas rupturas espaciais originadas de hierofanias se configuram por uma manifestação arquetípica, os espaços sagrados se assemelhariam uns aos outros, exemplo disso seriam espaços nos quais haveria o encontro entre esse mundo e o transcendente tais como: templos, cidades santas, santuários, montanhas sagradas, etc. (ELIADE, 1996).

Resumindo suas ponderações sobre o espaço sagrado, Eliade (1996, p.36) observa que "[...] a experiência do sagrado torna possível a 'fundação do Mundo' [...]"; o que não significaria ser apenas a projeção de um ponto fixo em meio ao espaço profano, mas sim que a manifestação do sagrado "[...] produz também uma rotura de nível, quer dizer, abre a comunicação entre os níveis cósmicos (entre a Terra e o Céu)[...]".

Nas teorias expostas anteriormente foi possível observar uma convergência entre as representações religiosas, a ação humana e a sociedade. Na geografia da religião costuma-se muitas vezes em prol do espaço diminuir a análise do elemento humano e social sobre a conformação do espaço. Quando se estuda o espaço, o sagrado é, mormente, apreendido como coisa espacialmente disposta, sendo que até mesmo em Eliade o sagrado é experiência qualificadora que organiza o cosmo através do espaço. 


\section{FUNDAMENTOS DA TEORIZAÇÃO}

\section{FILOSOFIA DE CASSIRER}

O que mais caracteriza o pensamento de Cassirer é sua Filosofia das Formas Simbólicas cujo principal mérito foi nivelar as manifestações da cultura humana numa posição de equidade. Através de Cassirer, o modo de pensar mítico e religioso não seria mais observado como manifestação de uma forma inferior ou patológica dos pensamentos humanos. Equivalente à ciência, à filosofia e à técnica, o mito e a religião seriam caminhos realizados pelo espírito na formulação de imagens do mundo.

\section{Símbolo, formas simbólicas e espaço}

Partindo de uma reflexão a respeito da unidade do ser, Cassirer pondera que sendo o conhecimento organizado por símbolos, sua significação fica a cargo de uma "estrutura conceitual lógica particular". Para o autor os objetos da física, da química e da biologia não são coincidentes nem ao nível da natureza, "[...] porque cada uma dessas ciências tem um ponto de vista particular na proposição de sua problemática e submete os fenômenos a uma interpretação e conformação específicas de acordo com este ponto de vista" (CASSIRER, 2001, p.16).

Tal fato acaba por relegar a unidade do ser ao âmbito do incognoscível. A partir disso, pondera o autor que para se resguardar a unidade do ser 0 ponto de partida não mais deveria estar na "unidade do substrato e da origem", mas em uma unidade funcional (CASSIRER, 2001, p.17-18).

Essa unidade funcional do conhecimento estaria ligada a uma função espiritual básica, a qual abrangeria diferentes formulações simbólicas. Partindo dessa função espiritual de simbolização o "[...] conhecimento (científico) por mais universal e extenso que seja seu conceito, representa apenas um tipo particular de configuração na totalidade das apreensões e interpretações espirituais do ser". O objetivo do conhecimento científico é simplesmente encadear num contexto um fenômeno individual, ou seja, "[...] inserir o 
particular na estrutura de uma lei e uma ordem universal” (CASSIRER, 2001, p.18).

Porém, junto ao conhecimento científico, trilhando caminhos diferentes, outras formas de objetivação levam o individual para o nível do universalmente válido. Essas formas específicas de objetivação são as formas simbólicas. Cassirer trata mais abertamente, nos três volumes da Filosofia das Formas Simbólicas, da linguagem, das manifestações mítico-religiosas e da ciência.

Cassirer várias vezes esclarece não serem as formas simbólicas espelhos que refletem imagens de um dado exterior ou interior, pois diferente disso elas são a própria condição para a visão e a origem dessas imagens. Dessa forma existe uma força criadora que transforma o caos das impressões sensoriais em formas mais delineadas. Essas impressões somente assumem forma e duração através da simbolização.

Sobre o símbolo, seu conceito abrange todos os fenômenos em que é dotado ao sensível algum tipo de sentido, nos quais esse sensível em seu "seraí" e "ser-assim" "[...] se apresente como particularização, manifestação e encarnação de um sentido" (CASSIRER, 1998, p.116). Cada forma simbólica possui uma forma característica de tornar uma impressão sensorial em símbolo.

O processo de simbolização é diferenciado, sobretudo, na relação existente entre o meramente sensível e o conteúdo espiritual que o significa, entre as coisas e as imagens. O processo que leva a transformação de um dado sensível a um significado simbólico atende há uma tripla gradação, às funções: expressiva, de representação e de significação (CASSIRER, 1998, 2001, 2004, 2005).

$\mathrm{Na}$ função expressiva não há separação entre a imagem e a coisa. Aqui uma imagem criada sobre um conteúdo sensível se torna o próprio conteúdo. Do ponto de vista da expressividade um ser recebe uma significação através da forma com que ele se revela no simples ato de ser, de existir. Dessa forma não se separa a aparência da realidade. A imagem não representa a coisa, ela é a própria coisa. Aqui não há uma divisão do conteúdo sensível em coisas e atributos, ao invés disso há uma relação afetiva com o mundo 
(CASSIRER, 1998). Na relação expressiva é oportuno observar que a significação do conteúdo sensível está diretamente relacionada ao afeto que tal conteúdo pode despertar no Homem. A forma simbólica nascida da relação expressiva com o mundo é o mito.

Ao contrário da expressividade, na função de representação há uma separação clara entre a imagem e a coisa, entre o símbolo e o conteúdo sensível. Aqui uma imagem, além de representar uma coisa torna essa coisa presente. Na função de representação a fixação de um significado a uma determinada coisa está diretamente ligada a sua fixação em unidades espaciais. Nesse ponto, cada coisa representada possui uma localização e se revela através de alguma forma espacial (CASSIRER, 1998, p.171).

$\mathrm{Na}$ função de significação as coisas do universo empírico não se confundem com suas representações. Diferente das anteriores, no qual a coisa e a sua imagem possuía uma estreita ligação, na função de significação há um desprendimento entre os fenômenos sensíveis e os conceitos. Aqui ocorre mais precisamente uma inversão, no qual o sensível é significado pelo conceito. A contemplação teórica do mundo significa as experiências antes mesmo delas acontecerem. A forma simbólica nascida dessa função de simbolização é a ciência (CASSIRER, 1998).

Apesar de assemelhar-se a uma escala, na qual a função de expressividade daria lugar à representação e essa última à significação, deve ser salientado que por mais avançado que esteja o conteúdo da consciência em direção à abstração, ele nunca se desconecta da expressividade primária (CASSIRER, 1998, p.134).

O símbolo, como união de conteúdo material e ideal, é marcado também por sua relação com o tempo e o espaço. Além do que, ao ser um mediador, o símbolo também é carregado de elementos corpóreos, do agir humano pelo tempo e sobre o espaço, as próprias formas simbólicas são ações realizadas pelo espírito humano em objetivar o mundo. Na filosofia de Cassirer o símbolo está ligado à materialidade e a ação humana, através de suas considerações não se deve conceber o símbolo apenas como uma representação ideal. 
Quando o autor questiona a maneira pela qual um conteúdo sensível particular torna-se portador de uma significação espiritual, logo demonstra que as particularidades sensíveis não se apresentam isoladas, mas antes estão integradas "em um todo da consciência". Totalidade essa constituída de modos específicos de associação, tais como: a)Momento de justaposição: de natureza espacial; b) Momento da sucessão: relacionado ao tempo; c) Relação de Causalidade.

Em cada forma de objetivação existe uma relação característica entre esses modos específicos de associação. Essas formas seguem cursos diferentes na integração dos elementos sensíveis num todo de consciência (CASSIRER, 2001, p.45-46).

As relações estabelecidas entre a justaposição e a sucessão, o espaço e o tempo, se conectam a relação conteúdo material/conteúdo ideal. A própria existência de uma "unidade subjetiva da consciência" e de uma "unidade objetiva do objeto" está relacionada a isso (CASSIRER, 2001, p.52).

O tempo é mais bem caracterizado pela sucessão, disso resulta que 0 instante temporal (o agora) não é estático, mas uma "transição fluída entre passado e futuro". Com o espaço haveria uma relação de justaposição, porém a apreensão de um todo espacial depende anteriormente da formação de séries temporais. Uma síntese simultânea da consciência com o espaço somente se completa com uma síntese sucessiva relativa às apreensões temporais. O que daria lugar a um sistema onde cada elemento espacial estaria em relação a outro (CASSIRER, 2001, p.50-54).

Além do espaço e do tempo existe outra forma de unidade hierarquicamente superior, a conexão objetiva. Ela oferece respaldo às múltiplas características que uma determinada coisa pode possuir sem deixar de ser essa mesma coisa. Se as sínteses sucessiva e simultânea fossem ponto de partida para formar um todo de um objeto, as diferenças pelas quais algumas coisas em determinados instantes se apresentam escapariam. Ao efetuar a formulação de uma coisa por suas partes seriam criadas coisas singulares imutáveis que dificilmente se repetiriam na série temporal e espacial elaborada. Para que isso não ocorra é preciso selecionar características que 
permanecem imutáveis para determinar o todo dessa coisa. Assim, sobre determinado objeto são retidas algumas característica que the oferecem particularidade, o que resulta em um todo no qual as partes somente são possíveis se estiverem inseridas nele (CASSIRER, 2001, p.56).

Essas relações entre o tempo, o espaço e a conexão objetiva, são o fundamento da representação. Cassirer procurou demonstrar que "[...] a representação de um conteúdo dentro do outro e através de outro constitui uma premissa essencial para a construção da consciência e a condição de sua própria unidade formal" (CASSIRER, 2001, p.61).

Um símbolo seria construído através da retenção em uma série de sucessões e justaposições de algumas características basilares de um objeto. As diferenças entre as significações desse objeto seriam relacionadas às peculiaridades referentes à modalidade das formas. Assim, o modo específico de produzir símbolos de cada forma simbólica estaria estreitamente relacionado às suas peculiaridades de estruturação do espaço e do tempo.

Mais especificamente em relação ao espaço não há produto ou qualquer outra criação do homem que não se refira de algum modo a ele (CASSIRER, 1998, p.181), ao passo que é a partir dele construída a própria realidade.

Por meio do espaço os fenômenos sensíveis seriam particularizados. Em meio à fluidez dos fenômenos sensíveis, numa corrente contínua de aparências, a consciência humana se realizaria através da retenção de algumas unidades básicas, as quais são remetidas há uma justaposição espacial (CASSIRER, 1998, p.171).

Porém a objetivação das coisas, ou mesmo, a constituição dessas coisas na consciência percorre caminhos diversos. Cada uma das modalidades de objetivação possui uma qualidade específica na forma de organizar as séries espaciais. No mito o espaço é um espaço de ação e expressão. Nas formas mais representativas da cultura, o espaço sofre um processo de simbolização, um esquema do pensamento no qual cada coisa ganha sua individualidade e à medida que essas práticas simbólicas avançam o espaço chega ao caráter de pura abstração. 


\section{Religião}

A religião enquanto forma de objetivação engendra um universo simbólico por intermédio das funções de expressividade e representação. Sua origem, do mesmo modo que o mito reside no choque da consciência existencial humana com a consciência de sua efemeridade material. O mito e a religião por ter origem na morte possuem aspectos comuns (CASSIRER, 2005, p.146).

A manifestação da religião através de um sistema de representações religiosas é o que melhor a diferencia do mito, caracterizado apenas pela expressividade. A identidade específica da religião é delineada através da capacidade espiritual de unir a elementos míticos um conhecimento organizado em tradições orais e escritas.

Essa mesma amálgama caracteriza a relação da religião com 0 espaço. Assim, a religião impregnada de elementos míticos se desenvolve num espaço saturado pelo modo mítico de sentir, ao se diferenciar do mito pela representatividade o espaço no qual o homem religioso se realiza também é representacional.

A intuição mítica de espaço se caracteriza por uma afetividade do homem para com o meio (CASSIRER, 2004, p.154-155). Através da atribuição de valores afetivos contrários, os locais e as direções espaciais são qualificados como sagrado ou não sagrado, o que reveste o espaço de diferenciações (CASSIRER, 2004, p.168-186). Assim, ao dispor sua função qualificadora pelo espaço, o pensamento mítico pode mais facilmente comparar e organizar as semelhanças entre suas produções espirituais (CASSIRER, 2004, p.155-156).

Essa qualificação afetiva dada ao espaço tem origem na oposição do dia em relação à noite, das quais se desprenderiam outras oposições tais como: luz e trevas, nascimento e túmulo, oriente e ocidente (CASSIRER, 2004, p.168-186).

Tudo que se apresenta no espaço como sagrado, manifestação de um deus ou demônio, é justificado através do tempo, a principal marca do 
pensamento mítico. No mito o tempo é visto como um vir a ser. As coisas presentes no espaço são desdobradas de um todo temporal. As divisões cronológicas seguem paralelas as subdivisões do espaço e, da mesma forma que esse, a cada fração do tempo é atribuída uma qualidade mítico-religiosa própria. A origem da divisão temporal também é alternância entre luz e escuridão, dia e noite (CASSIRER, 2004, p.186-196).

No entanto, no mito, o tempo não é constituído de duração e de sucessões regulares. Para a consciência mítica existem apenas determinadas figuras do tempo. Seu conjunto é formado por segmentos que, condensados e destacados através de um sentimento, marcam seus compassos, exemplo disso seriam os períodos rituais e os ritos de passagem. As transformações naturais ocorridas pela ação do tempo são observadas pelo homem como mudanças pessoais ou interferência de um deus ou demônio, daqui surge a tentativa de dominar os processos naturais através da mágica (CASSIRER, 2004, p.192,193,198).

O desenvolvimento da religião traz uma mudança na relação com o tempo. Cada religião enfatiza especialmente alguma fase do tempo, o que as caracteriza singularmente. As religiões monoteístas acabam por construir uma história para o futuro através das narrativas proféticas (CASSIRER, 2004, p.210-213).

As narrativas, atinentes à linguagem, oferecem à religião um caráter representativo. Diferente do mito, no qual as diversidades espaciais são construídas através de sensações subjetivas, na linguagem opera a função de representação (CASSIRER, 1998, p.183-184).

O espaço na função de representação se conforma como o esquema no qual a consciência fixa as particularidades das coisas concebidas. Assim sendo, a consciência humana frente aos estímulos das coisas presentes no universo sensível não os tomaria como dados novos, mas como um aparecer das representações, as quais, através desse aparecer, estariam inclusas num todo espacial (CASSIRER, 1998, p.171-193).

Para Cassirer a evolução das ideias mítico-religiosas ocorreu em conjunto com a da linguagem. Esta surge da mesma forma que o mito, através 
de uma emoção, de uma concentração da percepção em um determinado objeto. Dessa concentração pode surgir uma imagem mítica dotada de uma qualidade emocional específica ou uma imagem linguística. Desse ponto em diante há estreita relação no desenvolvimento de ambas às formas simbólicas (CASSIRER, 2006, p.52-55).

No desenvolvimento do pensamento mítico-religioso as configurações míticas se tornam mais definidas através da nomeação. Através da palavra um deus é trazido à existência, da mesma forma que a partir de suas palavras é criado o mundo e colocado ordem ao caos. No mito originariamente a própria Palavra possui poder.

\section{ANTROPOLOGIA DE GILBERT DURAND}

Ernst Cassirer pouco desenvolve na exposição de sua filosofia o mecanismo pelo qual surgem os símbolos da relação de expressividade. Sobre isso Cassirer recorreu a estruturas luminosas como o dia e a noite, além da relação do homem com a morte.

Para suprir esse déficit, um autor que servirá de apoio é Gilbert Durand, principalmente as contribuições dos dois seguintes trabalhos: As Estruturas Antropológicas do Imaginário (DURAND, 2002) e A Imaginação Simbólica (DURAND, 1993).

O autor defende que durante o desenvolvimento do pensamento ocidental houve uma constante marginalização da produção simbólica humana ao ponto de no século XIX ter esta um papel demasiado pequeno frente ao racionalismo. A retomada do estudo das imagens simbólicas ocorreu através das contribuições da psicopatologia e da etnologia. No entanto, essa redescoberta não oferecia ao simbólico uma autonomia, antes disso, essas contribuições visavam integrar e sistematizar as manifestações simbólicas em uma explicação intelectualista, para isso reduziam os símbolos a dados científicos. A essa hermenêutica o autor nomeou de redutora (DURAND, 1993, p.34-37).

Entre a hermenêutica redutora e aquela que instaura a importância do 
simbólico, Durand (1993, p.53-54) argumenta ser necessário situar a obra de Cassirer, a qual deve ser vista como um contraponto ou prefácio a todos os trabalhos realizados sobre a simbólica. Porém expressa o autor que Cassirer, mesmo oferecendo ao símbolo um papel de destaque, ainda efetua certa hierarquização das manifestações culturais, situando o mito como uma manifestação dinamicamente mais frágil que a ciência. As hermenêuticas instauradoras seriam aquelas em que ao simbólico é dada autonomia em relação à lógica. Os autores que melhor representariam essa hermenêutica seriam: Jung e Bachelard.

Na busca por construir uma antropologia do imaginário, Durand (1993, p.73-74) observou ter sido necessário eliminar os resquícios dos juízos de valor culturalmente herdados por alguns autores, como Cassirer e Bachelard, para os quais o racionalismo ainda se sobrepunha a outras manifestações culturais. Além disso, era necessário também não ver, como em Jung, o símbolo como uma síntese mental. Através dessas refutações o autor busca sistematizar as estruturas antropológicas do imaginário.

Em seu estruturalismo os símbolos são relacionados a três dominantes reflexas, as quais funcionariam "[...] como matrizes sensório motoras nas quais as representações vão naturalmente integrar-se." Essas dominantes reflexas seriam: a postural, digestiva e copulativa. Além disso, os símbolos são divididos em regimes diurno e noturno (DURAND, 2002, 47-58).

As dominantes reflexas quando associadas às representações são chamadas de esquemas. Por exemplo, "[...] ao gesto postural correspondem dois esquemas: o da verticalização ascendente e o da divisão quer visual quer manual, ao gesto do engolimento corresponde o esquema da descida e o do acocoramento na intimidade." Os esquemas seriam "[...] o esqueleto, o esboço funcional da imaginação" (DURAND, 2002, p.60).

Os grandes arquétipos são determinados pelo contato dos esquemas com o ambiente natural e social. "O arquétipo constitui o ponto de junção entre o imaginário e os processos racionais." O arquétipo é estável e dessa forma os esquemas de ascensão são correspondidos por arquétipos de cume e de chefe. Já os esquemas são substantificados pela constância arquetipal 
(DURAND, 2002, p.61).

Em relação ao símbolo Durand expressa que ao contrário do arquétipo, que possui característica universal e estável em relação ao esquema, os símbolos possuem sentidos diferentes e estão a caminho da substantivação, dessa forma "[...] enquanto o esquema ascensional e o arquétipo do céu permanecem imutáveis, o simbolismo que os demarca transforma-se de escada em flecha voadora, em avião supersônico ou campeão de salto." E nesse caminho um símbolo pode vir a se tornar um signo (DURAND, 2002, p.62).

Os Esquemas, os arquétipos e os símbolos compõem o mito. O qual seria para Durand (2002, p.62 63):

Um sistema dinâmico de símbolos, arquétipos e esquemas,
sistema dinâmico que, sob o impulso de um esquema, tende a
compor-se em narrativa. O mito é já um esboço de
racionalização, dado que utiliza o fio do discurso, no qual os
símbolos se resolvem em palavras e os arquétipos em idéias.
O mito explica um esquema ou um grupo de esquemas. Do
mesmo modo que o arquétipo promovia a idéia e o símbolo
engendrava o nome, podemos dizer que o mito promove a
doutrina religiosa, o sistema filosófico ou, como bem viu
Bréhier, a narrativa histórica e lendária.

A definição de mito do autor é semelhante à posição tomada por esse trabalho a respeito da nominação das experiências sensíveis. Durand oferece a essa teorização grande contribuição quando demonstra que a valoração negativa de arquétipos, esquemas e símbolos relacionados ao tempo e a morte oferecem uma excitação para o pensamento construir através do imaginário uma linha de superação.

Durand (2002, p.123) observa que transformar os males e as angústias em símbolos e imagens é uma forma de dominar esses infortúnios. Imaginar os terrores do tempo já abre a possibilidade de exorcizá-los. O imaginário pode derrotar os dragões que vivem no entorno da morte através de imagens que denotam armas. Para o autor o esquema ascensional, o arquétipo de luz uraniana e o esquema diairético são contrapontos à queda, as trevas e à carne. Esse seria o regime diurno da imagem, que caracterizado pelas estruturas esquizomorfas do imaginário promoveria através da antítese a separação, a 
oposição.

No regime noturno, caracterizado pela procura da constância na fluidez temporal, ocorre uma inversão do sentido afetivo da imagem. Nesse regime o antídoto em relação ao tempo ao invés da antítese será o eufemismo, no qual as imagens da noite, as quais lembram o tempo, se tornam positivas. No regime noturno imperam os símbolos cíclicos, de inversão e intimidade (DURAND, 2002 p.193-198).

Na conformação da religião há esse mesmo "esquematismo", no qual, para se fugir dos perigos do tempo e da morte, o imaginário humano se alimenta de alguns esquemas, arquétipos e símbolos, os quais através da objetivação são organizados pelo discurso em narrativas, em conhecimento religioso e através da ação humana espacializados.

Não obstante as objeções de Gilbert Durand à obra de Cassirer, a forma pela qual o primeiro organiza a simbolização no mito se comporta como um profícuo desenvolvimento teórico de uma lacuna deixada pela Filosofia das Formas Simbólicas, a questão sobre a produção do mito através da expressividade e seu encadeamento no fio de uma narrativa religiosa.

\section{ESPACIALIZAÇÃO DA RELIGIÃO}

As palavras concatenadas em narrativas religiosas são os primeiros veículos da difusão de uma explicação religiosa de mundo. Através da nomeação uma experiência religiosa individual pode ser narrada e transformada em uma experiência coletiva. Dessa forma discursos elaborados a partir de uma vivência mítico-religiosa se expandem territorialmente através do falar.

No entanto, a espacialização das ideias religiosas, ou seja, a relação de um sentimento, de um significado ou mesmo uma ação de dispersão e apropriação de caráter religioso sobre o espaço, se daria primeiramente através da expressividade.

Algumas experiências afetivas características da expressividade são relacionadas aos temores do tempo e da morte e se apresentam através de símbolos: teriomórficos (de animais), nictomórficos (das trevas) e catamórficos 
(de queda). Ao se deparar com os perigos da morte e a constelação de símbolos a ela relacionada, o pensamento humano buscaria exorcizá-los através de uma produção simbólica embasada em antíteses e eufemizações.

As imagens surgidas dessa experiência humana podem ser ancoradas e objetivadas (racionalizadas) no entorno dos enunciados religiosos. A religião, como forma simbólica, faz o entrelaçamento entre essa vivência pessoal expressiva e uma explicação de ordem geral representativa.

A espacialização de um discurso religioso se daria primeiramente no instante em que o homem busca explicar numa linguagem, no fio de uma narrativa, suas experiências afetivas com o mundo.

$O$ ato de nominar e explicar experiências sensíveis, em acordo com um conhecimento religioso objetivante, oferece ao homem a possibilidade de ordenar as coisas do espaço no enredo de uma explicação religiosa de mundo. Assim as sensações de uma coisa se tornam palavras, representações com origem temporal, posição espacial e relações de causalidade.

Em sociedades como a atual o olhar religioso já está impregnado por certas linguagens religiosas cuja origem remonta a um passado histórico ou imemorial. O primeiro passo na espacialização desses discursos foi dado pelo(s) organizador(es) da narrativa, pela habilidade de transformar experiências em verdades religiosas, as quais ao serem narradas a outras pessoas tiveram menos ou mais êxito na espacialização do nominar de experiências sensíveis com o mundo.

O caráter social de um sistema religioso se concretiza a partir da dispersão de seus enunciados. Quando uma verdade religiosa se torna veículo de objetivação da vivência expressiva de um número maior de pessoas tende a se espacializar mais nitidamente. O narrar da experiência religiosa propicia sua reprodução no nominar das experiências alheias. Assim, na posse da oralidade e/ou da textualidade pela qual se é difundido o saber religioso, o crente se torna agente de espacialização. Através de seu dizer as ideias religiosas se difundem pelo meio social e as representações contidas nos discursos se voltam ao espaço e são espacializados para além daquele espaço/tempo originário. 
Como exemplo é possível dizer que o êxito do cristianismo em sua dispersão espacial já estava potencialmente delineado na própria narrativa bíblica. Os evangelhos já incitam sua difusão quando narram as palavras proferidas por Jesus Cristo no momento de sua estada com os discípulos: "Ide por todo o mundo, pregai o Evangelho a toda criatura." (MARCOS, 16:15-16). As palavras proferidas por Cristo narrada pelo evangelista procuram exortar 0 enunciatário a ser, por meio de suas ações e palavras, um enunciador das verdades cristãs. Esse estímulo à difusão da narrativa expresso na própria narrativa marca profundamente o cristianismo como uma religião de missão. A espacialização do cristianismo se baseia desde início na difusão dos ensinamentos religiosos, o que se configurava como uma prova de amor ao próximo. Resultado disso foi o surgimento de manifestações evangélicas em vários lugares do mundo.

A enunciação das narrativas altera principalmente a relação do enunciatário com suas experiências expressivas. O conhecimento religioso auxilia na objetivação de um sentir primário, objetivando-o como experiências religiosas com o mundo. Através disso, o homem, impelido a agir em conformidade à forma pela qual vive e nomeia seu cosmos, transformaria o espaço, tanto no nível significativo, quanto material.

A vivência afetiva com o espaço significa negativamente ambientes imaginariamente povoados por animais "demoníacos", onde reinam as trevas, consuma-se à queda e a morte (abismo, vale obscuro, fundo do mar, interior da terra, etc.); através de antítese a esses espaços são afetivamente positivados ambientes de ascensão e purificação (cumes das montanhas, as torres, locais com luz banhados pelo dourado do sol e azul do céu), por meio de eufemização são positivados ambientes de segurança, intimidade e encontro como as navegações, a casa, o templo, etc. A narrativa religiosa oferece ao homem a possibilidade de objetivar essa afetividade primária de espaço e transpô-la a um espaço de representações.

Sendo a narrativa resultado do encadeamento de esquemas, arquétipos e símbolos no fio do discurso, as concretizações de algumas particularizações espaciais religiosas se encontram em estado de latência na 
própria afetividade humana.

O conhecimento religioso ao operar pela organização, divisão e significação das coisas presentes no espaço concreto e imaginário, auxilia 0 homem a ordenar o espaço e as coisas para qual dirige sua atenção e efetua suas ações cotidianas.

Dessa forma de organizar, dividir e significar o espaço a sacralização é força motriz. A dotação de qualificação diferenciada aos espaços obedeceria, por um lado às experiências expressivas e por outro às representações presentes no conhecimento religioso. O espaço sagrado se manifestaria em acordo com a narrativa obedecendo a funções de ascensão, purificação, segurança, Intimidade e encontro, da mesma forma o profano estaria relacionado a funções de queda e trevas. Ao invés do sacro se prender ao concreto, seu aparecer estaria anteriormente condicionado a imagem arquetípica e a função que esta representaria. Através disso as crenças, os ritos encontram um centro de referência, no qual o pensamento humano pode fixar mais facilmente a identidade das coisas religiosas.

No próprio ato da conversão, aqui compreendido como momento de escolha por uma forma religiosa para nomeação de um modo pessoal específico de sentir e viver o mundo, já se depara o novo fiel com a necessidade de construir um "script" temporal e espacial pelo qual pode situar os fatos, as coisas e as ações inscritas nesse conhecimento. Dessa forma os lugares sagrados viriam fortalecer sua percepção religiosa de mundo. Assim o processo de espacialização presente se retroalimentaria no processo passado. A sacralização de frações do espaço no decorrer da história é fortalecedora da espacialização atual.

Por significar o cosmo, a verdade religiosa seria muito mais que um "mero" conhecimento, seria a certeza das coisas e de seus sentidos. A própria existência humana se objetivaria num enredo em que o ser se consumaria em uma forma especifica de agir sobre o mundo. As verdades presentes na narrativa auxiliariam na construção de sentidos para a passagem do tempo, das coisas no espaço, bem como para um modo de ser no mundo. A verdade religiosa ao servir de alento as necessidades existências humanas seria peça 
chave na constituição dessa existência.

$\mathrm{Na}$ conclusão de sua obra Ensaio Sobre o Homem, Cassirer (2005, p.365) expressa que a vida cultural do homem gira em torno de uma incessante luta entre tradição e inovação, entre forças reprodutoras e forças criadoras.

Tal dualismo se expressaria com o passar do tempo na forma de grupos religiosos organizados. As organizações religiosas, erigidas no entorno de uma interpretação religiosa, tem por intento manter e perpetuar-se na tradição ou na inovação. Essa necessidade de proteger a verdade se conforma como um meio de conservação dos símbolos orientadores da vida, pois a negação de sua validade anularia as certezas existenciais de um grupo de pessoas; o que daria lugar a um vazio simbólico no qual o mundo deixaria de ter um significado ou seria ressignificado. Para essa ressignificação seria necessário outro conhecimento, outra interpretação de mundo. Assim as organizações religiosas seriam, muito mais que relações hierárquicas, sistemas instituídos para a defesa de um cosmo partilhado solidariamente.

Resumidamente e reiteradamente pode-se sistematizar a espacialização de uma linguagem religiosa da seguinte forma:

I. As experiências humanas com as feições do espaço são em primeira instância remetidas a sensações originadas do encadeamento entre os esquemas e o ambiente, as divisões do espaço são construídas através da afetividade.

II. Essa vivência expressiva pode ser objetivada por meio de um conhecimento. $O$ nomear dessas experiências através de uma narrativa propicia a organização de um cosmos pessoal religioso. As representações presentes nesse conhecimento oferecem sentido ao tempo e à ordenação do espaço.

III. O homem animado por esse modo religioso de nominar o mundo passa a exercer suas ações mentais e corporais pelo tempo e sobre o espaço, o construindo e o significando e assim perpetuando o referencial simbólico pelo qual objetiva sua existência.

Essas interações entre a expressividade, as representações religiosas e as relações discursivas nas sociedades resultam num processo de 
espacialização, cujos fluxos de retroalimentação podem ser visualizados na FIGURA 01 abaixo.

FIGURA 01 - ESQUEMA ESPACIALIZAÇÃO DA RELIGIÃO.

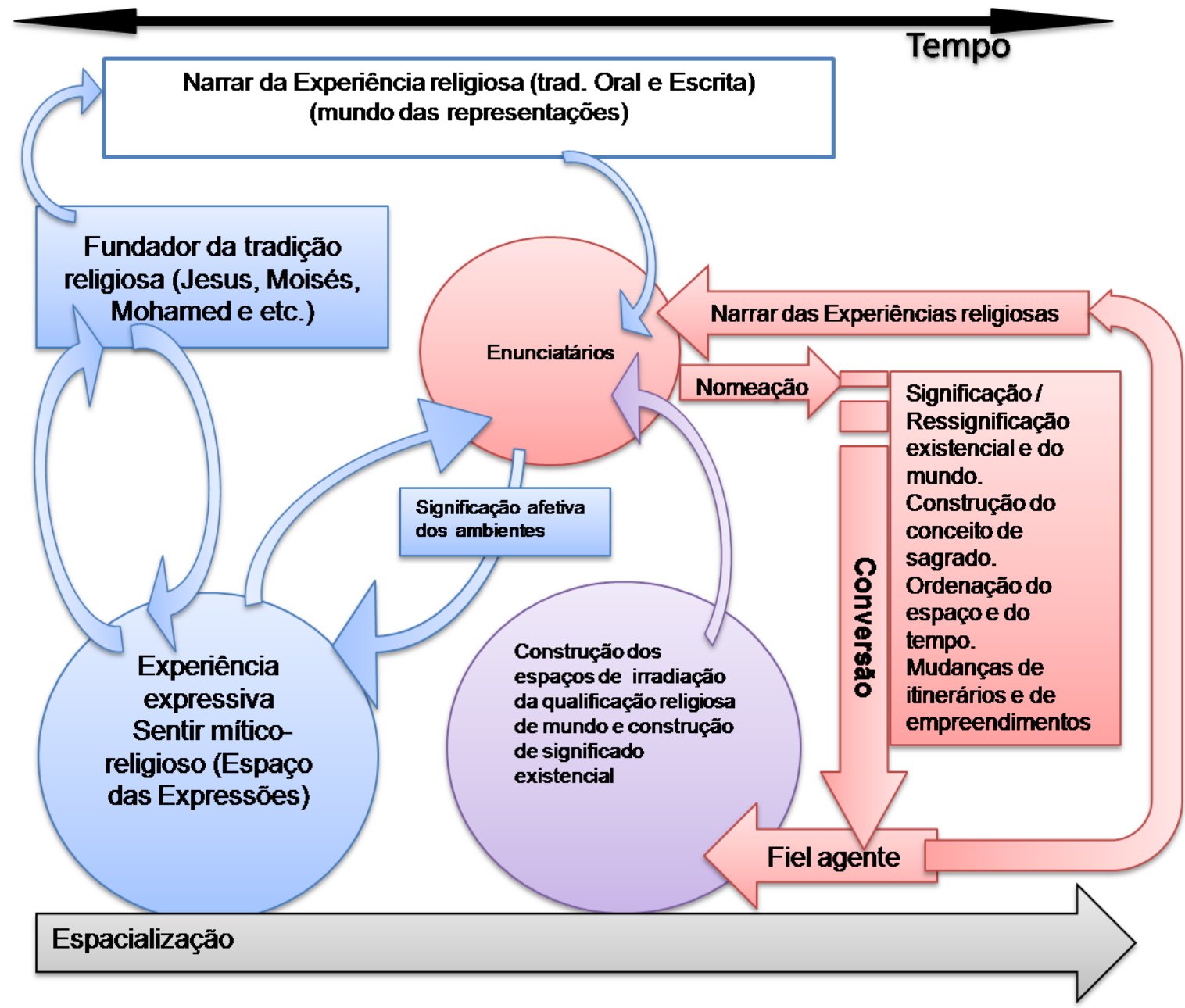

Elaborado pelo autor (2012)

\section{CONSIDERAÇÕES FINAIS}

Buscando responder às especificidades de algumas manifestações religiosas, inspirado nas teorias de Gil Filho e de Sahr é que expomos uma teorização para o processo de espacialização da religião.

Primeiramente, observou-se que a geografia muito se enriquece através de um diálogo mais aprofundado com outras disciplinas, nas quais a religião foi mais amplamente teorizada. De acordo com algumas contribuições 
oferecidas por essas disciplinas pôde-se argumentar que a religião, antes de se concretizar enquanto uma coisa espacial é ação humana com a transcendência por meio do espaço.

Partindo das contribuições do filósofo Ernst Cassirer e do antropólogo Gilbert Durand construiu-se de forma teórica um modelo para espacialização da religião. Observou-se que a dinâmica da espacialização está relacionada ao ato de objetivar experiências sensíveis por intermédio de um conhecimento específico. Assim, quando um homem objetiva um sentir, uma experiência primária com o mundo numa linguagem religiosa, passa a qualificar o espaço e agir de acordo com essa linguagem; e nisso o próprio ato de comunicar um conhecimento a respeito de uma experiência já seria um fator para a constante espacialização desse conhecimento. Através do nomear das experiências sensíveis pode o homem organizar todo o seu cosmos, suas ações e itinerários.

Essa teorização pode ser útil na explicação da construção espacial do cosmo vivido pelos fiéis de um determinado credo religioso. Através dessa forma de pensar a conexão da religião com o espaço é possível apreender as transformações ocorridas no espaço de ação de um recém-convertido e assim compreender a espacialização da religião. Em alguns sistemas religiosos 0 sagrado se organiza no espaço em vários níveis, observar a relação do sagrado com o espaço através da proposta apresentada nesse trabalho abre a possibilidade de desvendar níveis de espacializações pouco abordadas pelos geógrafos.

\section{REFERÊNCIAS}

BIRCK, B. O. O Sagrado em Rudolf Otto. Porto Alegre: Edipucrs, 1993.

BOURDIEU. P. Economia das Trocas Simbólicas. São Paulo: Perspectiva, 2009.

CASSIRER, E. Ensaio Sobre o Homem. São Paulo: Martins Fontes, 2005.

Filosofia das Formas Simbólicas I- A Linguagem. São Paulo: Martins Fontes, 2001. 
Filosofia das Formas Simbólicas II - O pensamento Mítico. São Paulo: Martins Fontes, 2004.

Fílosofia de las Forma Simbólicas III - Filosofia del Reconocimiento. México: Fondo de Cultura Económica, 1998.

. Linguagem e Mito. São Paulo: Perspectiva, 2006.

CLAVAL, P. Geografia da Religião. Espaço e Cultura: Rio de Janeiro, ํo 07, p.37-58, Jan/Jun1999.

DURAND, G. A Imaginação Simbólica. Lisboa: Edições 70, 1993.

Fontes, 2002.

As Estruturas Antropológicas do Imaginário. São Paulo: Martins

DURKHEIM, E. Sociologia e Filosofia. São Paulo: Ícone, 1994.

As Formas Elementares da Vida Religiosa: O sistema totêmico na Austrália. São Paulo: Martins Fontes, 2003.

Sociologia. São Paulo: Ática, 2005.

ELIADE, M. O Sagrado e o Profano. A Essência Das Religiões. $1^{\circ}$ ed. São Paulo: Martins Fontes, 1996.

FICKELER, P. Geografia da Religião. Espaço e Cultura: Rio de Janeiro, ㄲo 07, p. 07-35, Jan/Jun 1999.

GEERTZ, C. A Interpretação das Culturas. Rio de Janeiro: Guanabara, 1989.

GIL FILHO, S. F. Espaço de Representação e Territorialidade do Sagrado: Notas para uma Teoria do Fato Religioso. Ra'e Ga- O Espaço Geográfico em Análise: Curitiba, v.3, n.3, p. 91-120, 2000.

Geografia da Religião: Reconstruções Teóricas sob o Idealismo Crítico. In: KOZEL, S.; SILVA, J. C.; GIL FILHO, S. F. (Orgs.). Da Percepção e Cognição à Representação: Reconstruções Teóricas da Geografia Cultural e Humanista. São Paulo: Terceira Margem, 2006. Cap.10, p.207-222.

Por uma Geografia do Sagrado. In: MENDONÇA F. KOZEL, S. (Orgs.). Epistemologia da Geografia Contemporânea. Curitiba: UFPR, 2004, p. 253-265.

; GIL, A. H. "Identidade Religiosa e Territorialidade do Sagrado. Notas para Teoria do Fato Religioso". In: ROSENDAHL, Z.; CORRÊA, R. L. (Orgs.). Religião, Identidade e Território. Rio de Janeiro, EDUERJ, 2001, cap. 2, p.39-56.

KONG, L.: Geography and religion: trends and prospects. In: Progress in Human Geography. vol.14, №3, p. 355-371, 1990

MARCOS. In: BÍBLIA on-line: versão Almeida Corrigida Revisada Fiel. 2012. Disponível em: <http://www.bibliaonline.com.br/acf/mc/16>. Acesso em: $14 / 05 / 2012$ 
MARX, K; ENGELS, F. A ideologia Alemã. Lisboa: Presença, 1976.

OTTO, R. O Sagrado. Petrópolis: Vozes, 2007

PARK, C. C. Sacred worlds: an introduction to geography and religion. New York: Routledge, 1994.

ROSENDAHL, Z. Espaço e Religião: Uma Abordagem Geográfica. Rio de janeiro, EDUERJ, 2ª edição, 2002.

A geografia da religião no Brasil: 1989-2009. In. MENDONÇA, F; SAHR, C. L; SILVA, M. (Orgs.). Espaço e Tempo: Complexidade e desafios do pensar e do fazer geográfico. Curitiba: Ademadan, 2009a, p.289-312.

Hierópolis: O Sagrado e o Urbano. Rio de Janeiro, EDUERJ, 2009b.

SAHR, W. D. "O Mundo de São Jorge e Ogum: Contribuição para uma Geografia da Religiosidade Sincrética". In: ROSENDAHL, Z.; CORRÊA, R. L. (Orgs.). Religião, Identidade e Território. Rio de Janeiro, EDUERJ, 2001, cap.3, p. 57-68.

. Trois mondes entre íci-bas e au-delá. Reflexions postmodernes sur la géographie de la religion. Géographie et Cultures № 47, 2003, p. 45-66.

Signos e Espaços Mundos - A Semiótica da Espacialização na Geografia Cultural. In: KOZEL, S.; SILVA, J. C.; GIL FILHO, S. F. (Orgs.). Da Percepção e Cognição à Representação: Reconstruções Teóricas da Geografia Cultural e Humanista. São Paulo: Terceira Margem, 2006, cap. 3, p.57-79.

; MARINO, L. M. G. Em Contato com o Espaço do Além: Proposta para uma Geografia do Espiritismo. Revista Rever: São Paulo, p. 1-20, Jun. 2009.

WEBER, M. A Ética Protestante e o Espírito do Capitalismo. São Paulo: Pioneira, 2001.

. Ensaios de Sociologia. Rio de janeiro: LTC, 1982.

WACH, J. Sociologia da Religião. São Paulo: Paulinas, 1990.

Recebido em 10/03/2012.

Aceito em 01/10/2012. 